\title{
Hovering Architecture and Using Mirrors in Architectural Design
}

\author{
Vladan NIKOLIĆ*, Olivera NIKOLIĆ, Petar MITKOVIĆ, Srđan ŽIVKOVIĆ, Jasmina TAMBURIĆ
}

\begin{abstract}
The idea of the hovering effect of architectural structures is encountered throughout history; however, designs, interpretations and manner in which this effect is accomplished have changed. Modern technologies and current achievements regarding form have made the hovering effect interesting for both architects and conceptual artists. One of the ways of attaining the hovering effect in architecture worth considering is the use of either natural or man-made mirrors. The production of modern reflective materials has made it possible for architects to shape and create various designs in hovering architecture. The presented research is based on the Classification of the methods of achieving the hovering effect of architectonic structures. This classification is further expanded by the discussion and analysis of horizontal, vertical, oblique and curved mirrors. The novel and inventive way of their use contributes to achieving the effect that has been difficult or even impossible to achieve so far. The classification is expanded so as to represent a logical unity with the existing and improved ways of generating the effect by the use of mirrors. Moreover, it may be further improved by considering the concept known as invisible architecture and by relating it to hovering architecture.
\end{abstract}

Keywords: hovering architecture; invisible architecture; mirrors; symmetry; visual perception

\section{INTRODUCTION}

The idea of the hovering effect of architectural structures is encountered throughout history; however, designs, interpretations and manner in which this effect is accomplished have changed. This paper aims to contribute to the improvement of the Classification of the methods of achieving the hovering effect of architectonic structures [1]. Regarding the architectural design, there has been observed a significant transformation, actually an improvement regarding form since the nineties of the twentieth century, after the digital turn [2]. This was enabled by an overwhelming use of computers in architectural design and construction, as well as by the use of new building materials [3, 4]. Clouds Architecture Office is oriented towards the development of new architectural concepts, such as supertall skyscraper hangs from orbiting asteroid [5], whereas there have been started numerous projects on the Aerostatic Architecture Competition [6] (Fig. 1).
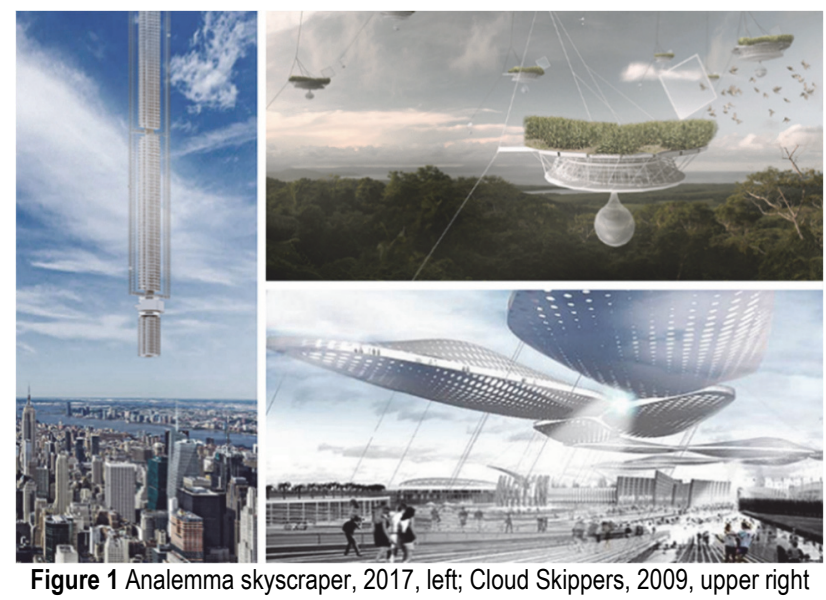

Figure 1 Analemma skyscraper, 2017, left; Cloud Skippers, 2009, upper right

(Clouds Architecture Office); Artificial Clouds, 2010. (Asadov Architecure Studio), lower right

The presented projects belong to the field of hovering architecture "on paper", i.e. theoretically speaking [1]. There is a growing tendency in the world to design buildings respecting the principles of hovering architecture, which can be exemplified by the Aerohotel, designed by Alexander Asadov. Patrick Kunkel posed the following question in 2015: "Could hovering buildings be the future of sustainability?", [7].

The hovering effect has become interesting not only for architects but also for numerous conceptual artists [8]. British artist and designer Alex Chinneck has played with this effect in his own particular and rather spectacular way. "A piece of the historic Covent Garden market appears to have broken free of its stone base, with its top half levitating in the air" [9] - a description of the structure officially presented in 2014 (Fig. 2). Chinneck says: "The hovering building introduces contemporary art to traditional architecture, performing a magic trick of spectacular scale to present the everyday world in an extraordinary way."

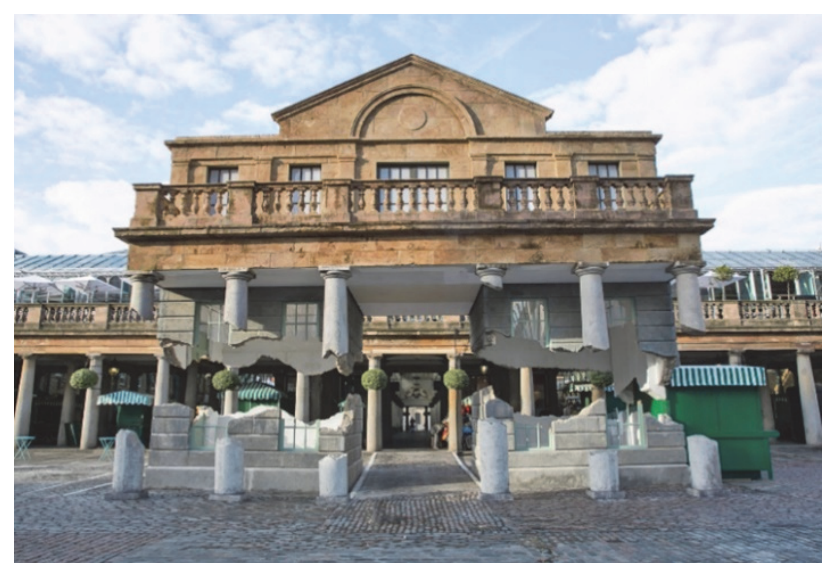

Figure 2 Covent Garden building installation, 2014 (Alex Chinneck) lalexchinneck.com/

In practice, hovering architecture is mainly about creating a visual effect which may be achieved in various ways. The desired illusion is most frequently obtained by geometrical installations and by shaping buildings, supports and the whole surrounding $[1,10]$. For example, in the Tourist info center in Knjaževac (Serbia), the hovering effect is achieved by the wide console overhangs and the shadow cast onto the surface by the consoles (Fig. 3) [10]. The illusion of the whole building levitating just above the ground is thus created. 


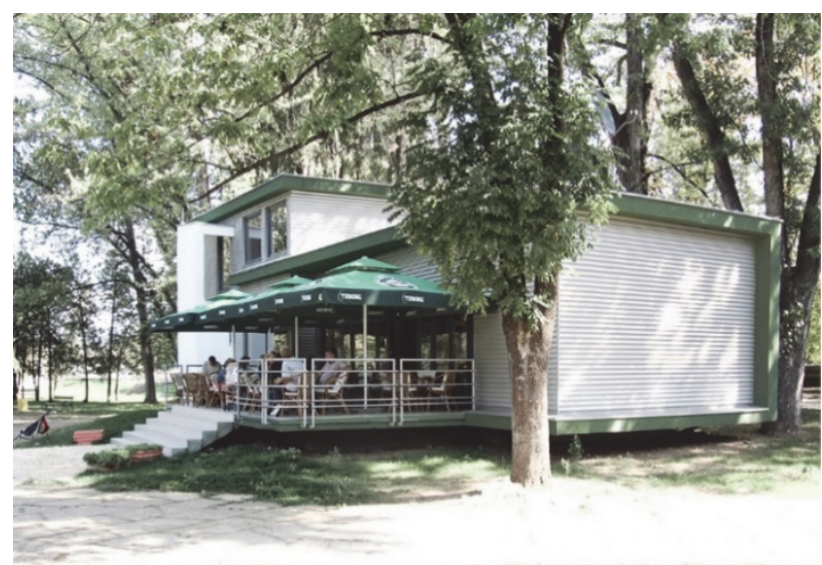

Figure 3 Tourist info center, Knjaževac, Serbia, 2007 (a free studio - Vladan Nikolić, Olivera Nikolić)

One of the ways of achieving the hovering effect in architecture worth considering is the use of either natural or man-made mirrors. The twenty-first century has seen the rise in the number of buildings designed on the basis of this concept, with "a new trend in architecture to use mimesis and optical illusions to create buildings that seem to deny their own existence" [11]. The achievement of the hovering effect in this case may be analysed as the visual perception of materials and their properties, mirrors, in fact [12]. The possible forms of this type of structures have not been systematised nor examined so far. This paper analyses and examines the aspects of the use of mirrors with the purpose of achieving the hovering effect in architectural structures. This article first determines the connection between hovering architecture and the use of mirrors, and then presents the expansion of the Classification of the methods of achieving the hovering effect of architectonic structures $[1]$.

\section{HOVERING EFFECT AND MIRRORS IN ARCHITECTURAL DESIGN}

The use of mirrors, as an integral part of an architectural concept, represents a possibility of creating optical illusions that may be the generators of the hovering effect. Architecture is the image we see [13] and an architect's ideas address the observer through that image. An observer is not able to see the complete architectural composition at once [14]. Bilateral symmetry is one of the most common types of symmetry, where the halves of a composition mirror each other [15]. Often, instead of bilateral symmetry, it is called mirror symmetry [16]. From the point of view of geometry, mirror symmetry plays a crucial role in achieving the hovering effect [14]. The illusion is created in the observer's perception [17]. Certain authors use the term mirrored buildings distorted perception [18].

Stilt houses were reflected in a natural horizontal mirror, the water surface, thus achieving the hovering effect, created then for utilitarian and safety reasons. Later, the effect generated by the water surface being acknowledged by numerous authors, it was used in almost identical ways. Itamaraty Palace in Brasilia, designed by Oscar Niemeyer, is surrounded by an artificial lake. The effect is especially striking at night by means of carefully installed ambience lighting [19], (Fig. 4).
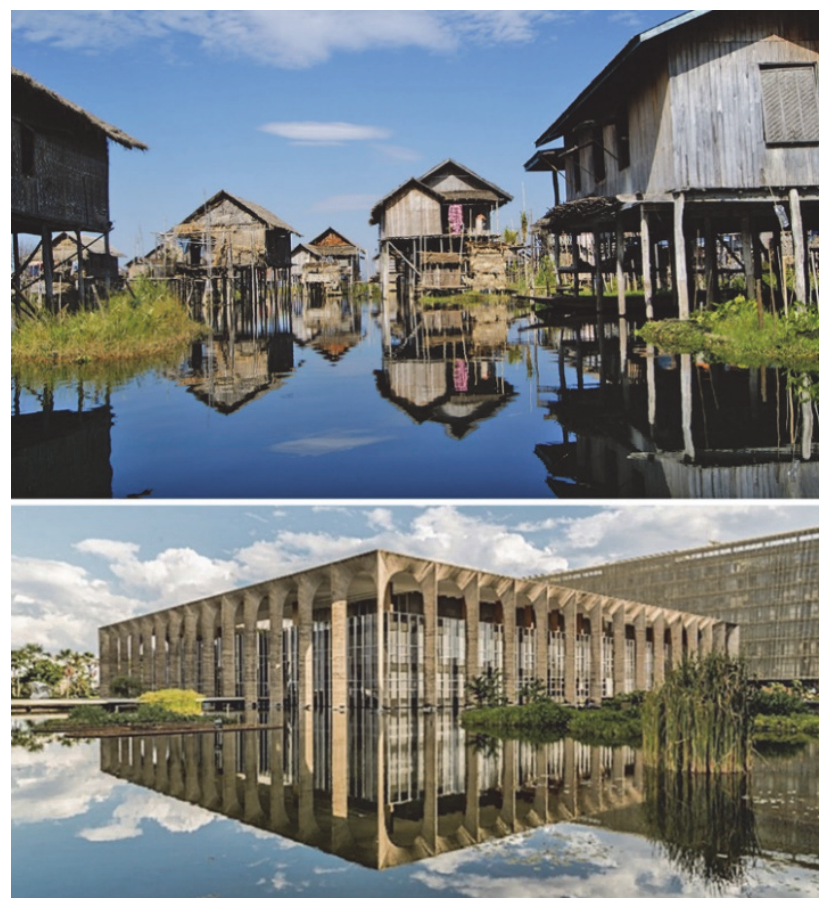

Figure 4 Example of stilt houses, City of Yawnghwe in the Inle Lake in Burma (wikimedia.org) and Itamaraty Palace, Brasília, 1960 (Oscar Niemeyer)
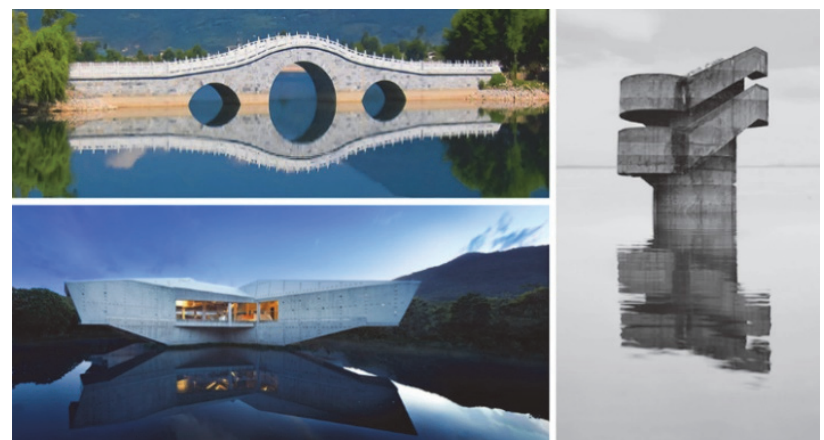

Figure 5 Water mirror /benjamindiewolfroep.co.za/ Observatoire III, 2013 (Noémie Goudal)/noemiegoudal.com/

Stamp house in Australia, 2013 (Charles Wright Architects) /archdaily.com/

The use of the water mirror does not require any particular engagement on the part of an architect or artist regarding the creation of the effect. The water reflective surface may be understood as a dynamic element, whose state is conditioned by the action of various external factors, such as wind, rain, etc. "By incorporating motion into architecture, designers give occupants another dimension by which to interact with their surroundings" [20]. It is precisely this effect that is used in the construction of numerous contemporary houses or public buildings, such as Beijing Opera House. Bridges are utility structures which, depending on the appearance and state of the water surface, become visually powerful "suspended" structures. In the context of hovering architecture, the new concepts of bridges, such as Webb bridge in Melbourne, are to be particularly emphasised [21]. Noémie Goudal, a visual artist, achieves the same hovering effect in his visual research [8]. Stamp house in Australia represents an extraordinary unity of the innovative form and natural mirror, which generates an extremely powerful hovering effect [22], (Fig. 5). 
The production of contemporary reflective materials has contributed to the creation of almost endless possibilities for architects to achieve the hovering effect in architectural structures. The power of the effect is based on a skilful and inventive use of mirrors. Reflective surfaces can be positioned in a number of various ways: horizontally, vertically, slanted or angled, curved or in the way which is the combination of the aforementioned. Michel Desvigne and Foster + Partners in Masterplan for Marseille's Vieux Port placed a horizontal reflective surface high above the line of the horizon, facing the ground. The canopy is supported by slender pillars. The canopy's polished, mirrored surface reflects the surrounding port, hovering in the mid-air above the ground, (Fig. 6 up). BIG architects had a similar approach when creating their winning design for the Stockholmporten masterplan in 2011 (Fig. 6 down) [23]. Erica Kim explained that "In order to create an interesting landscape form without majorly altering the actual topography itself, a reflective, self-sustaining hovering sphere mirrors the surrounding area, creating a 180 degree view of the city for the drivers below. The object serves as a visual icon and landmark that greets the entry point into Stockholm, reflecting the elements of the season and the urban life beneath it [24]". Chiara Tuffanelli has discussed the geometrical aspects of the use of spherical mirrors in architectural structures, analysing thus the Tall Tree and the Eye sculpture in the Royal Academy of Arts courtyard in London [25].
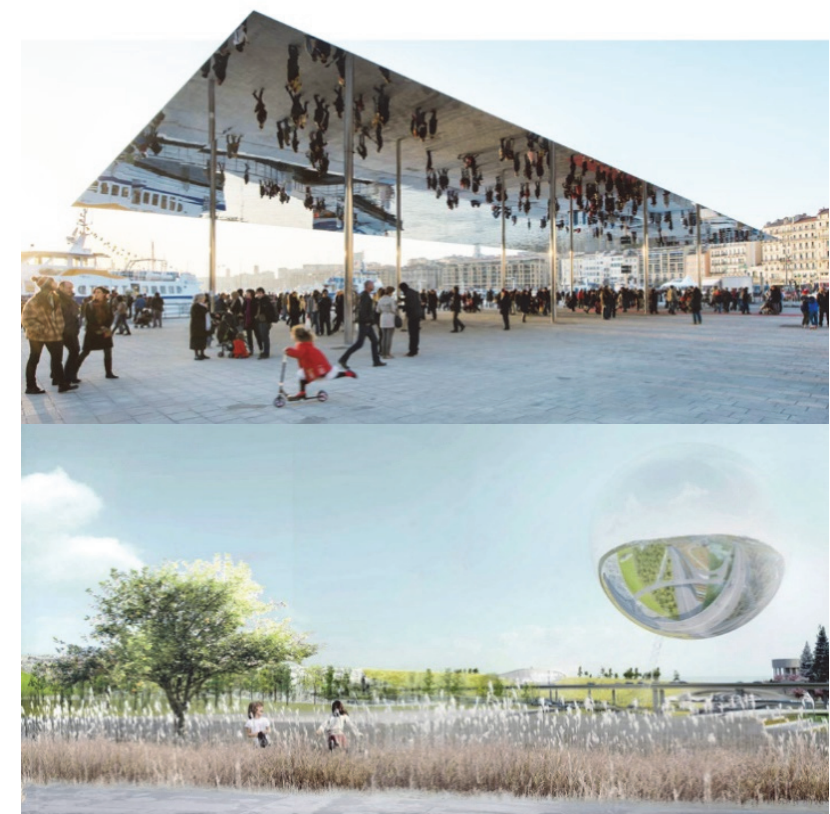

Figure 6 Mirror Canopy Pavilion, Marseilles, France, 2013 (Foster + Partners) larchdaily.com/ and Winning design for the Stockholmporten masterplan, Sweden, 2011 (BIG architects) /arkitekt.se/

\section{USING AND GEOMETRICAL SETUP OF MIRRORS IN HOVERING ARCHITECTURE}

The starting point of this paper is the Classification of the methods of achieving the hovering effect of architectonic structures. The classification is made according to the type of ground surface, as well as according to the $h / H$ factor (represents the ratio of the elevation of the observer's horizon $h$ and the elevation for which the entire structure, or some of its parts, is elevated above the surface $H$ ) [1]. In that classification, the structures are presented systematically in tables. The cases of the use of the natural water mirror have already been discussed and they belong to group A. The analysis of the use of man-made mirrors may contribute to the improvement of group B, which involves the structures positioned on the environment ground or above it. The obtained results are presented in the table in conclusion as the evidence of the improvement of the existing classification.

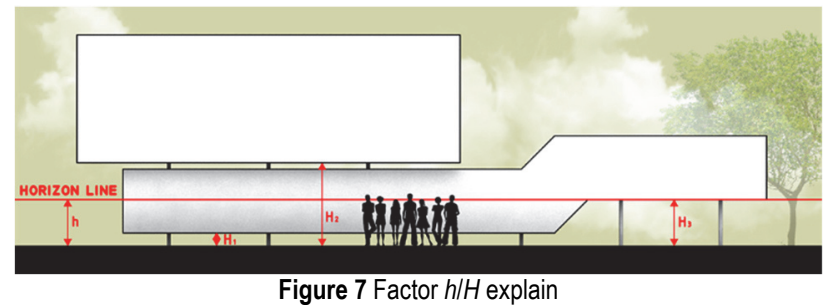

\subsection{Horizontal Mirrors Using}

The visual studies of achieving the hovering effect by means of using horizontally positioned mirrors were begun by the aforementioned Mirror Canopy Pavilion in Marseilles. This concept transforms reflection into a virtual object that floats above the horizon of the observer. The same method is applied in the construction of the New entrance plaza for EU headquarters in Brussels (Fig. 8). The ceiling overhauling the plaza is coated in materials of high reflection. The roof reflects the spherically shaped square, creating thus a surrealist image of a structure floating above the heads of the pedestrians. This image may be compared to the scenography of the film Upside Down from 2012.

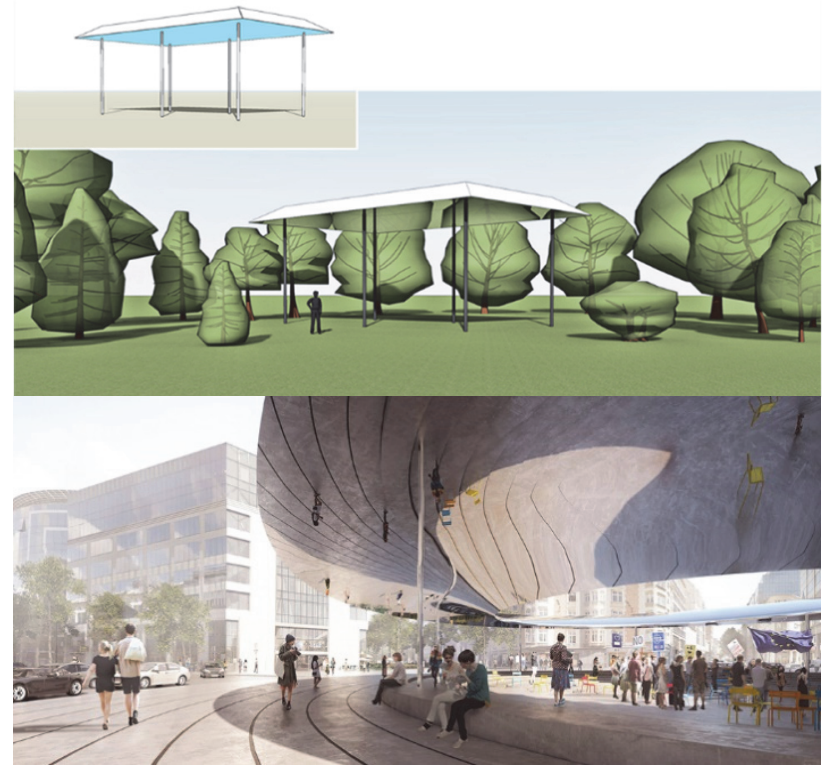

Figure 8 New entrance plaza for EU headquarters, Brussels, Belgium, 2018 (Architecture studios Cobe and Brut) /dezeen.com/

\subsection{Vertical Mirrors Using}

Vertical mirrors are most frequently placed along the edges of the building. A better effect is achieved if the height of the mirror does not exceed the line of the horizon. 
This is one of the basic ways of creating the hovering effect by means of vertical mirrors in designing the structures which are not detached from the ground. The example is to be found in the Floating cabins (Fig. 9). Those are modular houses that sit on ornamental mirrors that make the structures appear as if they are hovering a little bit above the ground [26].
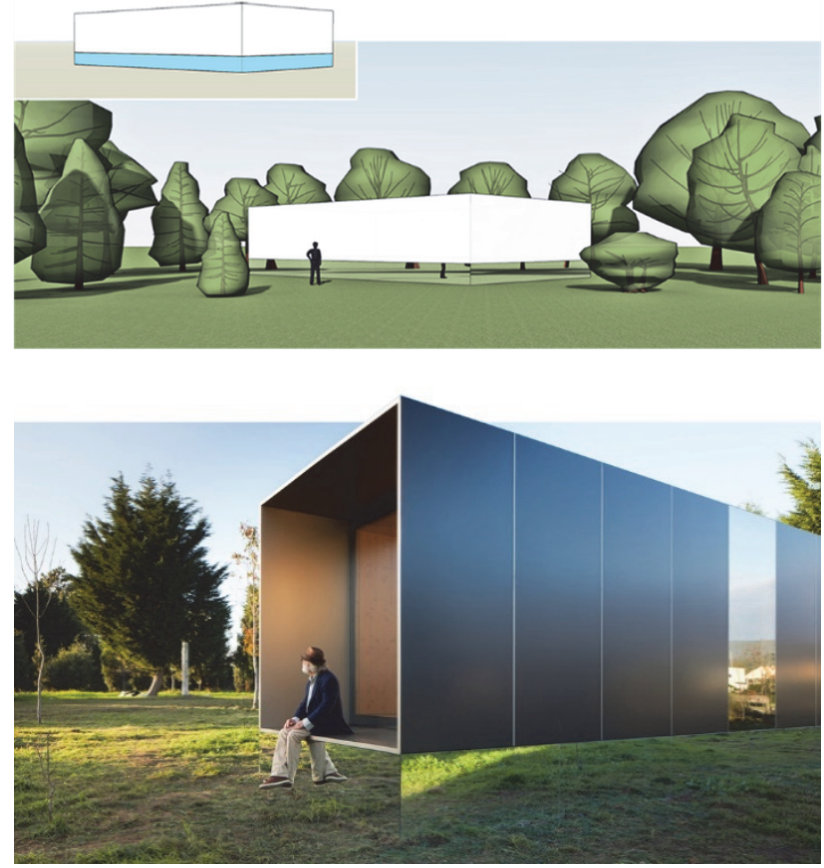

Figure 9 Floating cabins (Mário Sousa and Marta Brandão) /insidehook.com/

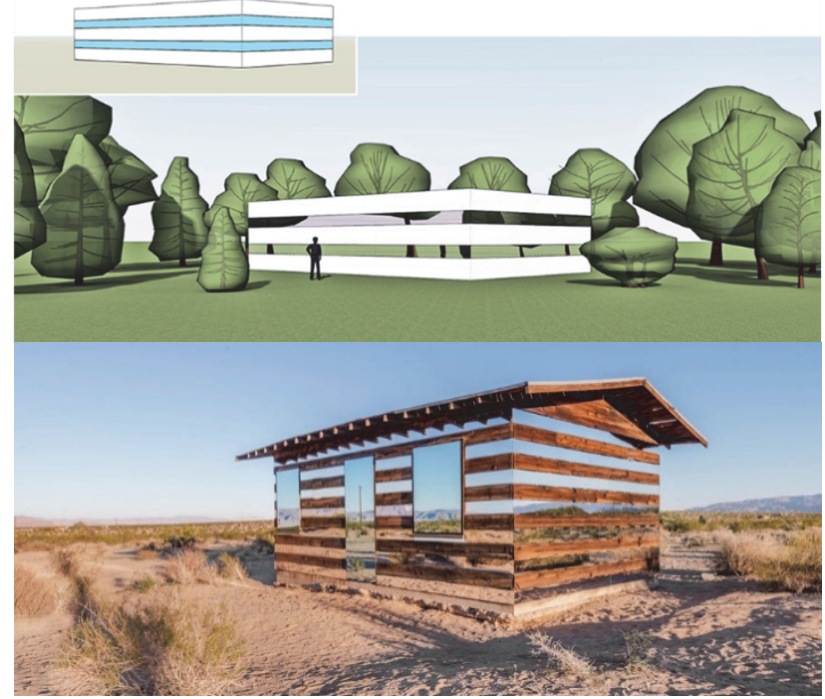

Figure 10 Lucid Stead, California Desert, USA, 2013 (Phillip K Smith III) /Steve King/

Respecting the principles of the aforementioned installation of mirrors, the American artist Phillip K Smith III conceived Lucid Stead in his own unique and inventive way in 2013, which is placed in the Californian desert. The old shack was covered in mirrored strips to create the illusion that you can see right through the building, or that parts of the building are floating [27].

Frequently applied variations of the aforementioned installations of vertical mirrors are to be found in the structures whose facades are completely covered in reflective materials. In these cases, the achieved floating or hovering effect is no longer dominant, since it is transformed into transparency, then immersion into the surrounding and disappearance. This trend is named Invisible architecture. A fine example of this type of design is the Pavilion for an Artist in Amsterdam (Fig. 11).

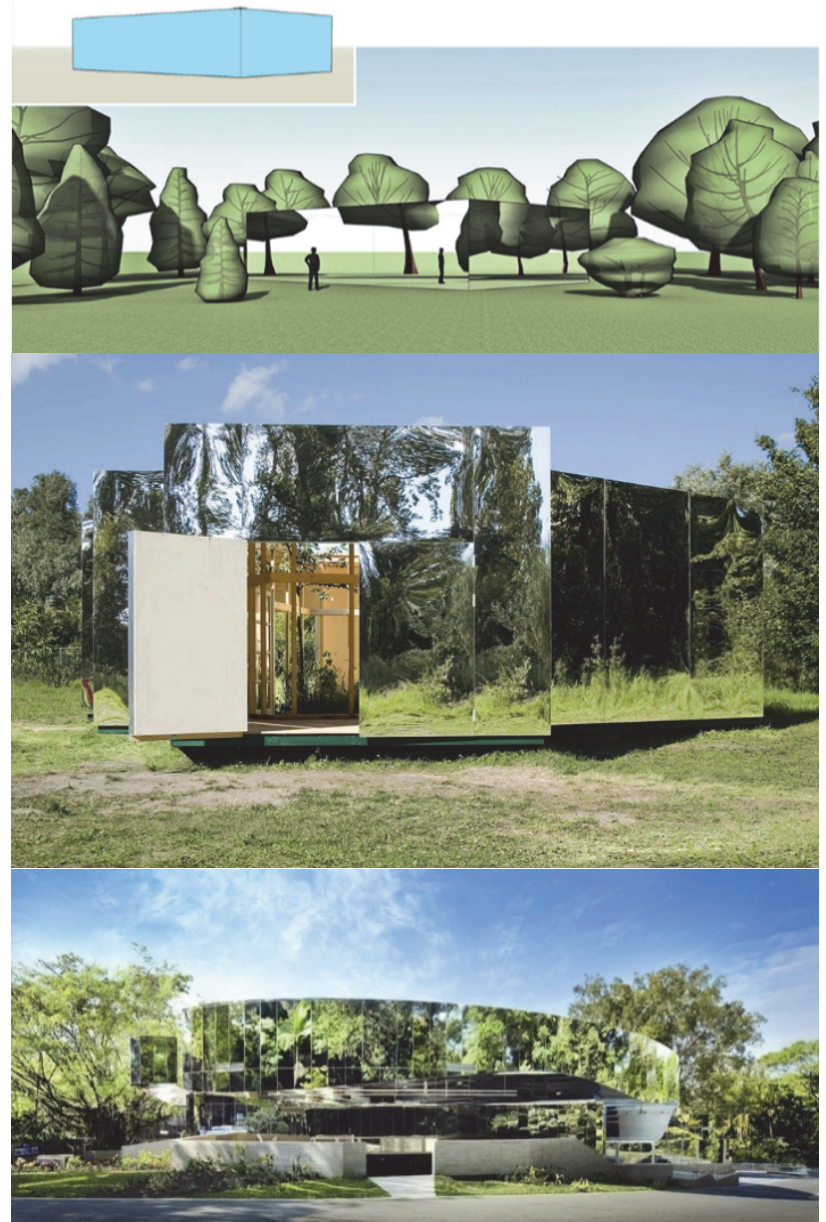

Figure 11 Pavilion for an Artist, Amsterdam, The Netherlands, 2008 (DHL Architecture) /Thomas Lenden/ and Cairns Botanic Gardens Visitors Centre, Australija, 2011 (Charles Wright Architects)

One of the best examples of the use of mirrors and the ensuing floating effect is the Izabelin House in Poland (Fig. 12). Authors of the house said "it is a two-storey mirror house concept that is formed of two horizontally configured blocks. The house's lower storey is clad with reflective panelling. The second floor appears to float above its mirrored base, a levitating box that will hover in the thick forest" [28]. In this type of structure, the existence of two volumes is of the crucial importance, one of which is on the ground floor and the other above the line of the horizon of the observer. The ground floor of the building may be panelled by vertical mirrors, which create the floating effect of the upper floor. This geometrical installation can be interpreted differently, which makes it susceptible to various visual research

French architect Herault Arnod took on the challenge of designing a modern renovation for an old brick garage workshop located in Pas-de-Calais. The glass and steel renovation updated the existing garage with a hovering volume. The metallic extension block appears to hover over the original building [29]. 

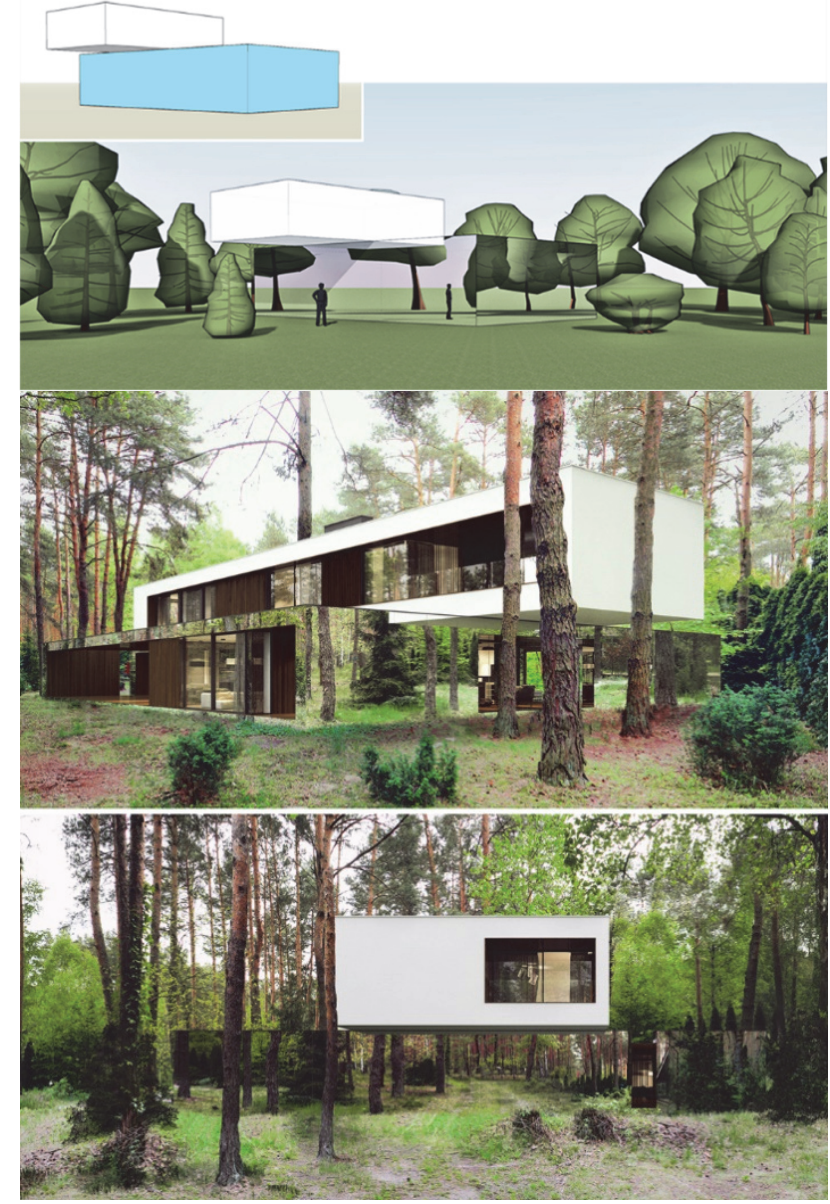

Figure 12 Izabelin House, Izabelin, Poland. 2014 (REFORM Architekt) /Marcin Tomaszewskil

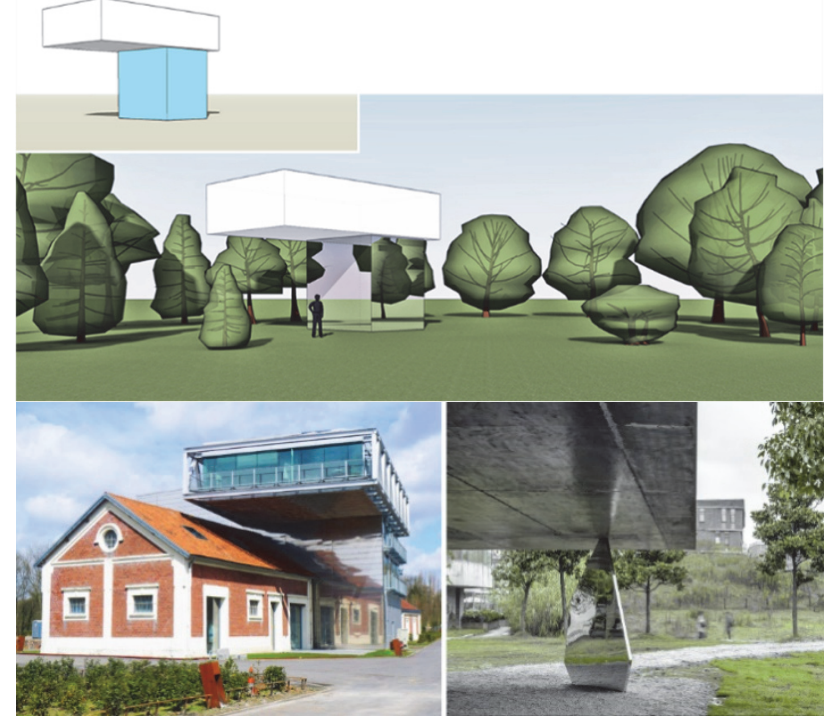

Figure 13 Glazed hovering extension, Pas-de-Calais, France, 2014 (Hérault Arnod Architectes) /inhabitat.com/ and Blossom Pavilion, Shanghai, China, 2015 (Atelier Deshaus) /archdaily.com/

Fig. 14 shows an example of invisible architecture applied in one part of the building. The building shown is the Vakko Fashion Center \& Power Media Centre. Its volume of the last storey is panelled by the reflective glass. Besides reflection and the invisibility effect, achieved under particular conditions, the hovering effect is achieved by means of visual withdrawal, orientation and separation of the upper volume from the main volume of the building.
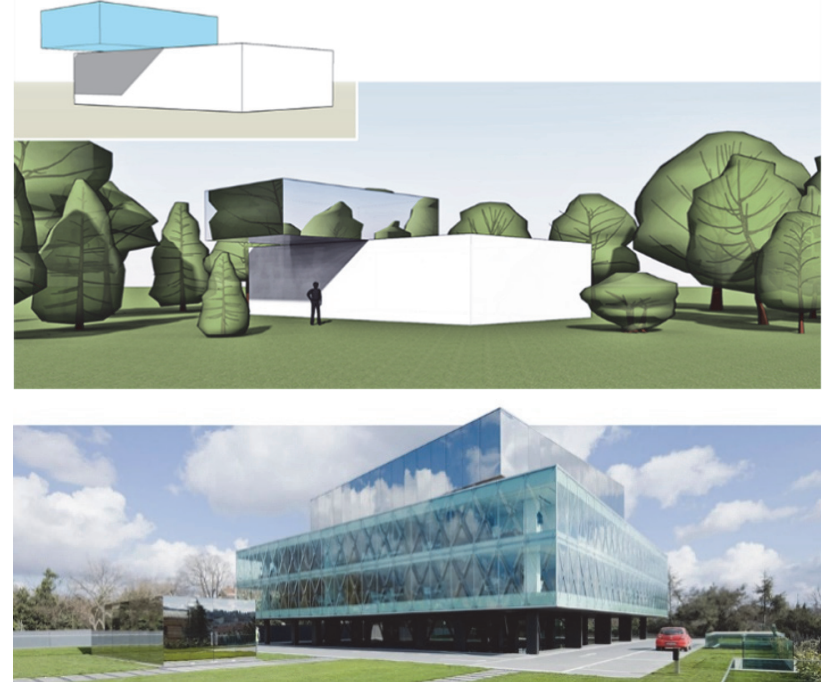

Figure 14 Vakko headquarters and power media center, Istanbul, Turkey, 2010 (REX) /i.pinimg.com/

\subsection{Oblique and Mixed Mirror Positions Using}

When using oblique mirrors in creating the hovering effect, it is preferable to use the mirrors whose height exceeds the line of the horizon. At lower heights, this installation would not have a better effect than the use of simply positioned vertical mirrors (Fig. 15). This concept of mirrors is rare in practice and can be seen in parts of buildings whose shape is rather complex and innovative, such as the Paläon Research and Experience Center in Germany.

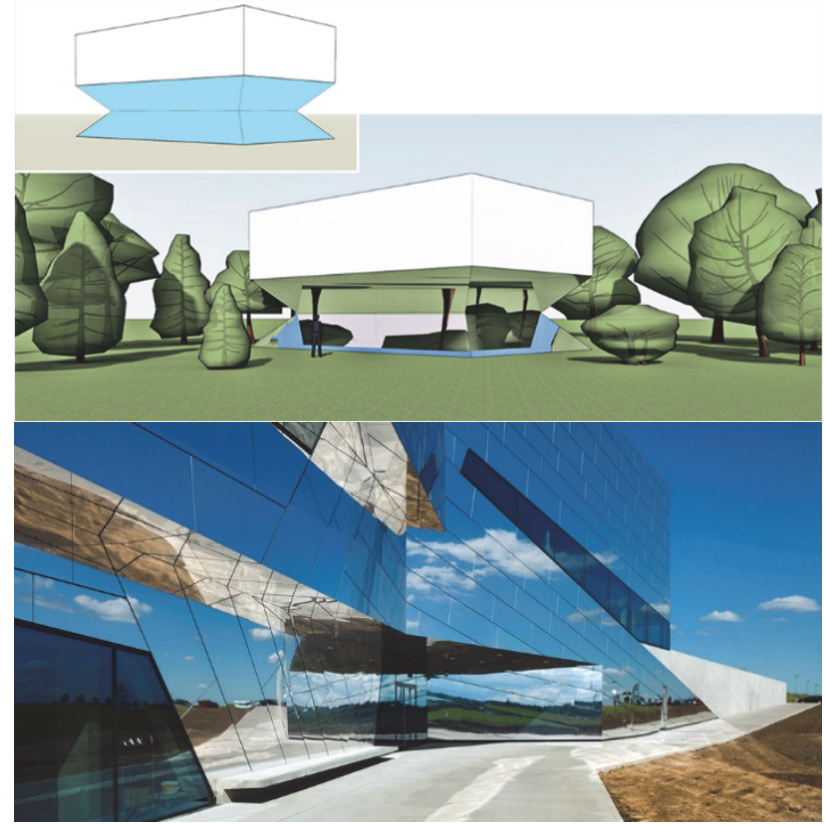

Figure 15 Paläon Research and Experience Center, Schöningen, Germany, 2013 (Holzer Kobler Architekturen) /archdaily.com

The combination and mixture of several mirrors cause their interaction that generates complex optical illusions for observers and residents. The Argentinian artist Leandro Erlich created a surreal artwork in London in 2013. It was the installation of a nineteenth century Victorian house built with mirrors, with a façade constructed on the ground (Fig. 16), [30]. 


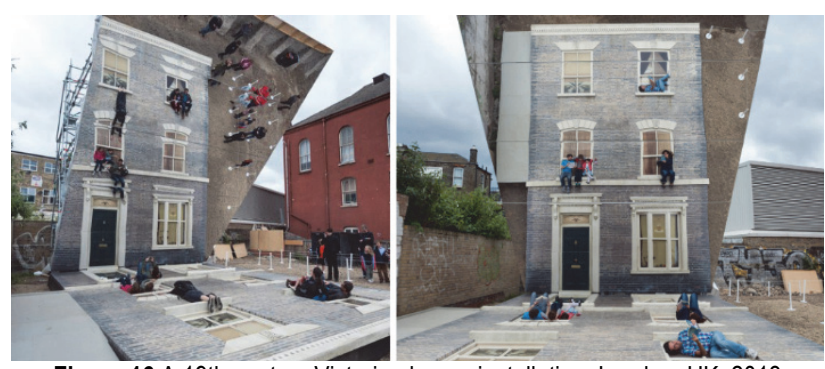

Figure $16 \mathrm{~A}$ 19th century Victorian house installation, London, UK, 2013 (Leandro Erlich)/tmagazine.blogs.nytimes.com/

In hovering architecture, mirrors are mainly used when the building cannot be physically detached from the ground, either because of its structure or its function. In such cases, a skilful and inventive use of mirrors is one of the ways of achieving the illusion of floating of the whole building or of some of its parts. The use of mirrors creates the hovering effect, achieved in the whole building or in its parts, best illustrated by the example of Mark's House (Fig. 17). The house is clad in reflective panels on top of a mirrored pedestal, giving the structure the appearance of floating in mid-air [31].

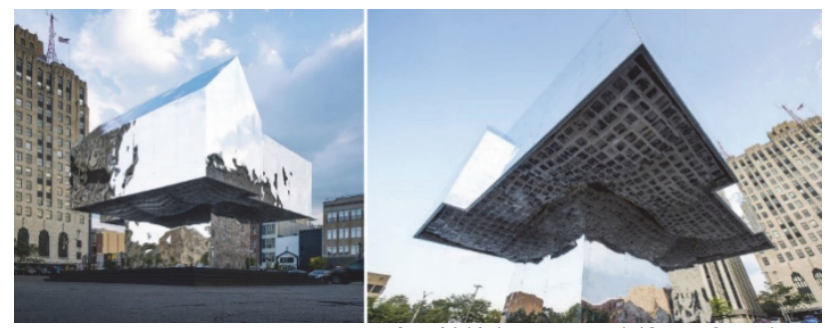

Figure 17 Mark's House, Flint, USA, 2013 (Two Islands) /Gavin Smith/

\subsection{Curved Mirrors using}

The use of curved mirrors represents a technological innovation that has become practically feasible in large buildings in the twenty-first century. Artists and architects have recognised the perspective of the use of curved mirrors, which create a particular group of buildings whose aesthetics is based on the principle of hovering and invisible architecture [32] (Fig. 18). The works of Anish Kapoor, the sculptor specialising in installation art and conceptual art, occupy a special place in the study of shape of curved mirrors.

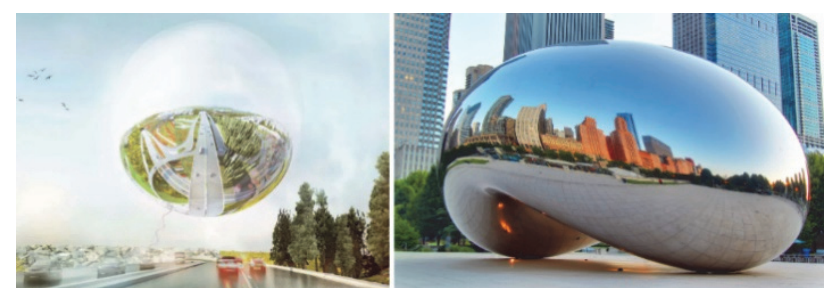

Figure 18 Stockholmporten master plan, Sweden, 2011 (BIG architects) larkitekt.se/ and Cloud gate, Chicago, USA, 2006 (Anish Kapoor)

\section{CONCLUSION}

Contemporary architecture is based on the use and application of innovative technologies and materials. Their inventive use contributes to achieving the effects that were difficult or almost impossible to achieve in the past. Reflective surfaces made of various materials are used in creating new interpretations of hovering architecture.
These surfaces are most frequently flat horizontal, vertical or oblique surfaces, or their combinations. Spherical and freely curved monolithic surfaces represent a challenge both in the sense of their shape and in the sense of their construction. They are mostly used in conceptual art.

The analysis of the presented geometrical installations of mirrors leads to a conclusion that it is possible to create two groups that sublimate the possibilities of forms. These two groups are expanded by the already existing classification, so that they all represent a logical unity, improved by new ways of generating the hovering effect by means of mirrors. The expansion of the classification is shown in Tab. 1. The use of reflecting materials is one of the fundamental ways of designing structures whose concept is known as invisible architecture. Therefore, the concept of hovering architecture is evidently related to the concept of invisible architecture. Further improvements should implement this component into the classification. This means that the development of the integrated concept of hovering/invisible architecture is feasible.

Table 1 Addition to classification of the methods of achieving the hovering effect of architectonic structures (Structures/Land)

B Structures / Land

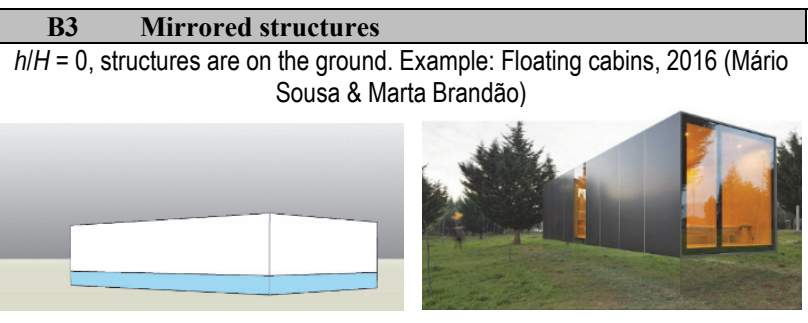

$\mathrm{h} / \mathrm{H}<1$, the height of hovering part of the structure above ground is higher than the horizon line. Examples: The 7th room, Sweden, 2017 (Snøhetta) and Vineyard House, Santorini, Greece, 2019 (Kapsimalis Architects)
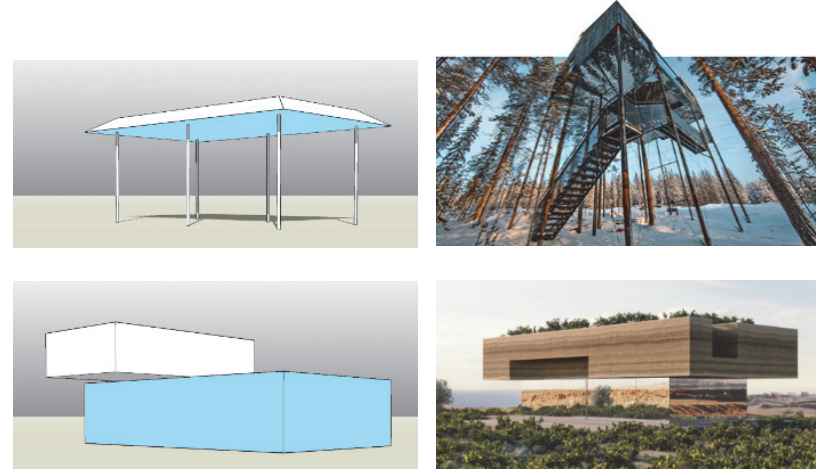

\section{Acknowledgements}

The authors express their gratitude to the Ministry of Science and Technological Development of Serbia for providing partial support for this project (Grant No. TR 36037).

\section{REFERENCES}

[1] Nikolić, V., et al. (2016). Proportional Ratios and Geometrical Setups for Achieving the Hovering Effect of Architectonic Structures. Technical Gazette, 23(2), 579-588. https://doi.org/10.17559/TV-20140628181558

[2] Carpo, M. (2013). AD The digital turn in architecture 19922012. John Wiley \& Sons. https://doi.org/10.1002/9781118795811 
[3] Tulika, M. \& Chiueh, T.-C. (2000). Three-dimensional computer graphics architecture. Current Science, 78(7), 838846.

[4] Addington, M. \& Schodek, D. (2005). Smart materials and new technologies: for the architecture and design professions. Routledge.

[5] Mairs, J. (2017). Supertall skyscraper hangs from orbiting asteroid in Clouds Architecture Office concept. Retrieved from https://www.dezeen.com/2017/03/23/ supertall-hanging-skyscraper-asteroid-clouds-architectureoffice-concept-analemma-tower

[6] "The Future City" exhibition at RIBA, as part of "Foresight Future of Cities".

Retrieved from http://www.bmiaa.com/future-city-riba

[7] Kunkel, P. (2015). Could Hovering Buildings be the Future of Sustainability? Retrieved from www.archdaily.com/769169/could-hovering-buildings-bethe-future-of-sustainability/

[8] Goudal, N. (2013). The Geometrical Determination of the Sunrise. Arles: Actes Sud.

[9] Winston, A. (2014). Alex Chinneck performs architectural "magic trick" with Covent Garden building installation. Retrieved from https://www.dezeen.com/2014/10/02/alex-chinneck-takemy-lightning-but-dont-steal-my-thunder-levitating-housecovent-garden/

[10] Nikolić, V. \& Nikolić, O. (2007). Prikaz konkursnog rada i izvedenog objekta Turističkog info centra u Knjaževcu. Nauka + Praksa, 10, 51-55.

[11] Subirats, D. (2019). Invisible Buildings: A New Trend in Architecture that Can not be Seen. Retrieved from https://www.azureazure.com/homes/architecturedesign/invisible-buildings/

[12] Fleming, R. W. (2014). Visual perception of materials and their properties. Vision Research, 94, 62-75 https://doi.org/10.1016/j.visres.2013.11.004

[13] Tierney, T. (2007). Abstract Space Beneath the Media Surface. Abingdon: Taylor \& Francis. https://doi.org/10.4324/9780203965825

[14] Nikolić, V., Radović, L., \& Marković, B. (2015). Symmetry of "Twins". Symmetry, 7(1), 164-181. https://doi.org/10.3390/sym7010164

[15] Williams, K. Symmetry in Architecture. Retrieved from www.mi.sanu.ac.rs/vismath/

[16] Hargittai, M. \& Hargittai, I. (2009). Visual Symmetry. Singapore: World Scientific Publishing. https://doi.org/10.1142/7042

[17] Robinson, J. (1998). The Psychology of Visual Illusion. New York: Dover Publications.

[18] Brandt, J. \& Mackavey, W. (1981). Left-right Confusion and the Perception of Bilateral Symmetry. International Journal of Neuroscience, 12(2), 87-94. https://doi.org/10.3109/00207458108985793

[19] Rossetti, E. P. (2010). The Itamaraty Palace in Brasilia. Docomomo Journal, (43), 66-69. https://doi.org/10.52200/43.A.D7ROBAKF

[20] Zeinab, E. (2010). Sustainable vision of kinetic architecture. Journal of Building Appraisal, 5(4), 341-356. https://doi.org/10.1057/jba.2010.5

[21] Murray, P. (2015). Future Architecture, a Journey into the Architectural Future of the World. Murray Books.

[22] Stamp House / Charles Wright Architects (2013). Retrieved from https://www.archdaily.com/335695/stamp-housecharles-wright-architects?ad medium=gallery

[23] Lambert, L. (2012). Weaponized Architecture: The Impossibility of Innocence. Barcelona: dpr.

[24] Kim, E. (2011). BIG architects: Stockholmsporten master plan winning design. Retrieved from http://www.designboom.com/architecture/big-architectsstockholmsporten-master-plan-winning-design
[25] Tuffanelli, C. (2010). Mirrors and Spheres: The Geometry within the "Tall Tree and the Eye". Proceedings of Bridges Conference, 51-58.

[26] Floating Cabins are Actually Just a Deceitful Illusion. (2016). Retrieved from www.insidehook.com/nation/mimamirrored-floating-cabins

[27] Frearson, A. (2013). Lucid Stead installation by Phillip K Smith III. Retrieved from https://www.dezeen.com/2013/11/ 23/lucid-stead-installation-by-phillip-k-smith-iii/

[28] Izabelin House / REFORM Architekt (2015). Retrieved from https://www.archdaily.com/office/reform-architekt

[29] Lisa, A. (2014). Herault Arnod Transforms an Aging Brick Garage into a Gleaming Modern Office. Retrieved from https:/inhabitat.com/herault-arnod-renovates-an-agingfrench-bricked-garage-into-contemporary-glazedoffices $/$ ?variation $=\mathrm{d}$

[30] Redstone, E. (2013). A 19th-Century Victorian House in London, Built with Mirrors. Retrieved from https://tmagazine.blogs.nytimes.com/2013/06/25/themaking-of-a-19th-century-victorian-house-in-london-builtwith-mirrors/? $\mathrm{r}=0$

[31] Mark's House. (Two islands) Retrieved from $\mathrm{http}: / /$ www.twoislands.net/moma-marks/

[32] Albu, C. (2016). Mirror Affect: Seeing Self, Observing Others in Contemporary Art. University of Minnesota Press.

\section{Contact information:}

Vladan NIKOLIĆ, PhD, assistant professor (Corresponding author)

Faculty of Civil Engineering and Architecture, University of Niš Aleksandra Medvedeva 14, 18000 Niš, Serbia

E-mail: vladan_nikolic@yahoo.com

Olivera NIKOLIĆ, PhD student, assistant

Faculty of Civil Engineering and Architecture, University of Niš, Aleksandra Medvedeva 14, 18000 Niš, Serbia

E-mail: o_milosavljevic@yahoo.com

Petar MITKOVIĆ, PhD, full profesor

Faculty of Civil Engineering and Architecture, University of Niš Aleksandra Medvedeva 14, 18000 Niš, Serbia

E-mail: dekan@gaf.ni.ac.rs

Srđan ŽIVKOVIĆ, PhD, associate professor

Faculty of Civil Engineering and Architecture, University of Niš Aleksandra Medvedeva 14, 18000 Niš, Serbia

E-mail: srle.26@icloud.com

Jasmina TAMBURIĆ, PhD, assistant professor Faculty of Civil Engineering and Architecture, University of Niš, Aleksandra Medvedeva 14, 18000 Niš, Serbia

E-mail: ministo@yahoo.com 